\title{
Performing Difference: Diversity, representation and the nation Dominic Hingorani
}

THE AUTHOR: ... and you an immigrant too? The Indies? A Caribbean princess, arrived on these shores across an exotic sea?

THE GREENER: Whatever? East London me.

THE AUTHOR: But surely. How can I put it? You seem a bit.... dark?

THE GREENER: East End everyone is different, so everyone belong.

Doesn't matter where you're from. To be straight, how can I put it? It's you what sticks out like a sore thumb.

(Hingorani 2016, 92)

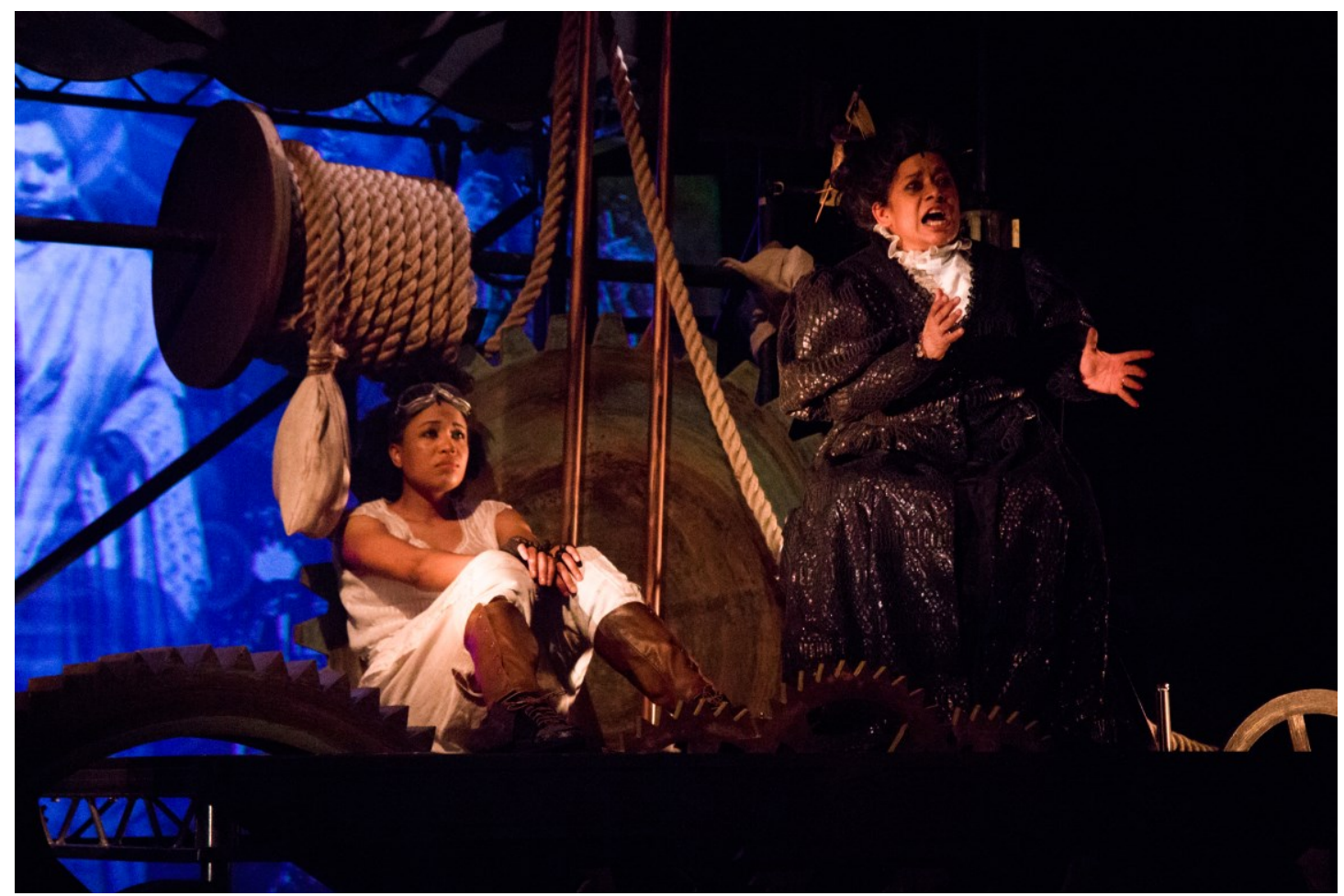

From left: Keisha Atwell playing the greener and Patricia Rozario O.B.E. as Ma Photograph by Fresh Label

The eponymous hero of the title of the new opera work Clocks 1888 the greener by Brolly Productions is a mixed race teenage girl from the East End of London, not a character we would usually expect to see centre stage in this art form. The name of this character 'Greener' is taken from the Victorian cockney slang term for immigrant and as the extract above suggests is applied ironically in the context of the opera; in this respect it is the Greener who is 
constructed as 'local' whilst the Author, the well-to-do, white, 'gentleman' from the West End who is de-centered as the 'foreigner' or 'other'.

In this respect, projects such as Clocks 1888 the greener draw on local histories, diasporas, heterogeneous cultural location of geographies such as those of the East End of London as a catalyst for performance works that are rooted in 'difference' to create innovative hybrid forms of 'emancipatory, utopian performances, texts grounded in distinctive styles, rhythms, idioms and personal identities of local folk and vernacular culture' (Denzin 2003, 123). In the case of Hackney, East London, in which The Hackney Empire is located, the production performed the ethnic profile from the Census, showing evidence 'of continued increasing diversity, with sizable White British (36.2\%) and Black African communities (11.4\%) but also a large and increasing group of residents from mixed and 'other' ethnic backgrounds, emphasising the hyper-diversity of the borough' (2011).

Brolly created and produced the new opera work Clocks 1888 the greener at Hackney Empire in spring 2016 and was supported by Arts Council England with the clear brief to engage new and diverse audiences and thereby challenge the perception of opera as an elitist art form and re-root it within communities. The audience engagement strategy was threefold in this respect: to create an opera work in which the characters on stage and their stories in performance reflected the diversity and cultural histories of the prospective audience; to host symposia events that supported the development of networks between that diverse potential audience and other cultural organisations; to share our creative methodology that led to the development of the opera by creating an open access microsite Clockwork1888.co.uk. A further key feature was to keep ticket prices to a level that would not exclude our target audience which was made possible by public subsidy.

The chapter will examine how Clocks 1888 the greener engages with cultural diversity as a methodological tool to create an innovative hybrid form that aims to engage with community audiences, address issues of representation and articulate a performative 'counter narrative' to challenge exclusionary and racist constructions of the nation. It will explore how an active artistic engagement with the different histories, cultures and diasporas of communities 
can support notions of inclusion and accessibility and open pathways for participation and civic engagement.

\section{Thinking through Diversity}

The drive by those wishing to address discrimination and increase the representation and access to the arts, especially of those from minority communities, has been articulated around the signifier 'diversity'. However, I would suggest from the outset we may more usefully think through the imperative of cultural inclusion by mobilising a theoretical discourse of 'difference' rather than 'diversity' which inherently suggests 'totalised cultures that live unsullied by the intertextuality of their historical locations' (Bhabha 1994, 34). Further, the internally and externally marked heterogeneity of minority groups needs to be conceptualised culturally and creatively if we accept the view of Sir Peter Bazelgette, Chair of Arts Council England (ACE), that 'Britain's got many, many talents... and our work should reflect and engage with all our talent and communities' (Bazalgette 2014).

To view the current politics of 'Diversity' that gathers disparate minority communities under its banner, it is worth revisiting the nascent political signifier, 'Black', that emerged in the late 1970s and acted as a 'new focus of identification for both Afro-Caribbean and Asian communities...not that they are culturally, ethnically, linguistically or even physically the same but that they are treated as 'the same' (i.e. non-white, “other") by the dominant culture' (Hall 1992, 308). While, 'Black', was an important site of resistance, reclamation and solidarity that encompassed heterogeneity, a mantle that the term 'Diversity' could wear, it paradoxically could not articulate the difference that was recognised or rewarded by public funding. Importantly, the current drive for inclusion under the banner 'Diversity' endeavours not only to build minority representation across the arts with regard to race, sexuality, gender, disability and age but also one predicated importantly on the responsibilities of the funded companies and organisations to achieve it. Indeed, as Madani Younis, Artistic Director of The Bush Theatre points out, in the past the “responsibility for diversity, which should be everyone's responsibility, had been abandoned to a few companies" (Younis quoted in Bazalgette 2014). 
BME led organisations were for many years tasked by ACE with bringing in the 'missing' BME audience, something not axiomatic and an abnegation of the responsibility of the sector as a whole. Further, it became extremely reductive in its creative and artistic ramifications, exemplifying the paradox that, whilst the marginal position of many BME led organisations enabled them to access funding, the conditions of that funding insisted on their artistic product remaining displaced to the margins. While ACE has continued with the designation of BME, which it defines as $51 \%$ or more of the organisations' board and senior management being from a Black or minority ethnic background, as a necessary funding priority which attempts to level the field, as a category it is culturally heterogeneous . Bhabha's rejection of the concept of cultural diversity on the grounds that it is a comparative discipline, allows us to focus instead on how communities' cultural difference(s) can be articulated to contest marginalisation in the arts and develop innovative hybrid forms which are predicated on a construction of the nation as "the otherness of the people as one" (Bhabha 1994, 142).

Benedict Anderson defined the nation as "an imagined political community" $(1983,6)$ and describes how it is "imagined as a community because regardless of the actual inequality and exploitation...the nation is always conceived as a deep horizontal comradeship” (ibid. 7). While the conception of a "deep horizontal comradeship" is still a worthy aspiration, we must recognise the potential of the arts as a site from which to contest "inequality and exploitation", especially in relation to issues of race and representation. We can look to Bhabha's approach to a construction of the nation above as an extremely eloquent turn of phrase for inscribing difference into the fabric of the national consciousness. The identification of a temporal split or "double time" in the construction of the nation, categorised as the "pedagogical" and "performative" moments, creates a signifying space for those on the margins. Firstly, in the pedagogical moment, the people are the "historical 'objects' ...giving the discourse an authority that is based on the pregiven or constituted historical origin in the past" (Bhabha 1994, 145) which by its nature militates against the inclusion of the newly arrived and diasporic. Secondly, however, Bhabha points out that the people are also the 'subjects' of the repetitious, recursive strategy of the performative... [in which] the scraps, 
patches and rages of daily life must he repeatedly turned into the signs of a coherent national culture (ibid).

The opera attempts to recognise the importance of this contemporary 'performative' moment especially when we consider the 'hidden' pre-war presence of ethnic minorities in Britain, the large scale immigrations of Black and Asian peoples to postwar Britain, as well as the more recent diasporic and European migrations. These more recent migrations from Eastern Europe support the case of diversity as a fluid conception, necessarily in process and responsive to change and heterogeneity, destabilising fixed ideas of geographical areas being homogeneously allied to particular ethnic groups. It is to these particular, local, lived and shifting environments or sites of 'hyper diversity' to which arts must meaningfully respond if we are to achieve a radical new engagement with diverse audiences and artists and a potential reconceptualisation of the nation. It is from this contemporary site of the 'performative' that marginalised 'counter narratives', as Bhabha describes them, can emerge to contest and challenge the centre in order to 'disturb those ideological manoeuvres through which 'imagined communities' are given essentialist identities' (Bhabha 1994, 149) and problematise the term 'diversity' with its insinuation of separate and discrete categories of cultural designation that remain fixed and intransigent, impervious to time and circumstance disavowing notions of fusion, syncretism and hybridity. The 'performative' provides a locus for BME artists to contest attempts to stereotype or 'other' in a way that 'reduces, essentializes, naturalises and fixes difference' (Hall 1997, 258) and insists on the recognition and inscription of 'difference' being written onto the body of the heterogeneous nation.

The inclusion of diverse voices, cultures, histories, vernaculars, is vital but also the recognition that culture(s) are always 'in play' so that 'difference' is a "process of signification through which statements of culture or on culture differentiate, discriminate and authorise fields of force, reference, applicability and capacity" (Bhabha 1994, 34) which undermine attempts at the creation of a homogeneous cultural supremacy. Indeed, it is crucial that minority communities authorise 'fields of force' to culturally contest the centre in order to effect change and that the centre also responds unequivocally in kind. 
I suggest that we mobilize Stuart Hall's concept that we inhabit "cultures of hybridity" which recognises that while people from BME communities in Britain "bear upon them the traces of the particular cultures, traditions, languages and histories by which they were shaped” (Hall 1992, 310) or 'difference', they also have had to "renounce the dream or ambition of rediscovering any kind of 'lost' cultural purity or ethnic absolutism" (ibid). Importantly, those from 'cultures of hybridity' inhabit a 'diaspora space', as conceptualised by Avtah Brah, that is "inhabited not only by those who have migrated and their descendents but equally by those who are constructed and represented as indigenous" (Brah 1996,181). I will suggest the opera attempts to artistically animate that 'diaspora space' to provide a culturally heterogeneous site of play in which 'difference' can be articulated in non-hierarchical, inclusive and hybrid creative ways.

\section{The Drive for Diversity - Arts Policy in the UK}

Sir Peter Bazalgette, Chair of Arts Council England, signaled a clear shift in public arts policy in relation to diversity in his keynote speech titled, 'Arts Council and the Creative Case for Diversity' (2014), which recognized that up until this point the prevailing orthodoxy that had been to support BME led organisations was “fine, but as a consequence we didn't nurture diversity in all our work, across all our funded organizations and their audiences". This renewed policy focus on diversity, and more importantly the recognition of the continued lack of diversity and representation for minority communities in the arts was developed by actor Idris Elba in his recent keynote speech to Parliament titled, 'Diversity in the Media', on 18 January 2016 as he insisted that "diversity in the modern world is more than just skin colour - it's gender, age, disability, sexual orientation, social background and most important of all, as far as I am concerned - diversity of thought” (2016). Elba's impassioned plea was not only arguing for a broader view of diversity, ably dismissing the suggestion that minority groups lack a vision of inclusion beyond their own borders, but also the breadth of imaginative potential when cultural borders are crossed. Indeed, the position set out in this chapter is that serious engagement with diversity is not only a creative force for innovation but can also act as a 
model of inclusion so that "the arts won't have to make the case for diversity. The arts will simply be the case" (2014).

It is worth setting out a brief historiography of public subsidy for the arts in relation to the representation of minority and marginalised groups to contextualise the on-going attempts to achieve the long heralded 'level playing field' today, and the historical endeavors that first recognised the importance of creating a diverse team in the first instance. I take as my starting point Naseem Khan's seminal report in 1976, 'The Arts Britain Ignores: The Arts of Ethnic Minorities in Britain', and what was then identified as 'ethnic arts' which was the first to officially recognise that 'ethnic arts' should not be regarded as an exotic extra outside of British theatre but should be understood, funded and fostered as though they were a part of British Theatre. Over the intervening years many such reports from those advocating 'inclusion' have been published, not least, 'The Eclipse Report - Developing Strategies to Combat Racism in Theatre' (2002), which was influenced by the Macpherson Report (1999) and its recognition of institutional racism, in this case in the theatre. Yet, the heavy lifting of institutional change was too often left to small or medium scale BME led companies such as, Tara Arts, Tamasha Theatre, Talawa, Nitro, and Kali Theatre, to name but a few, who made important artistic interventions predicated on diversity but were without the infrastructure, capacity or indeed long term fiscal support to affect such sector wide change.

Sir Brian McMasters' report, 'Supporting Excellence in the Arts - From Measurement to Judgement' (2008), was unequivocal on diversity and states that, "we live in one of the most diverse societies the world has ever seen, yet that is not reflected in the culture we produce, or in who is producing it" (11). The statistical headlines in the 'Equality, Diversity and the Creative Case' (2015) report sets out across National Portfolio Organisations (NPOs) that 'progress' in relation to ethnicity is not only stalled but in reverse:

Sticking with our current definition, looking at the leadership of the 2012-15 and 2015-18 National Portfolio Organisations, the number of Black and minority ethnic-led organizations reduced by 4 to 52; and the number of disability-led organisations reduced by 4 to 9 over the same period; there is clearly work to do. 
Crucially, the McMasters report not only recognised in stark terms the lack of diversity in the arts but was also responsible for broadening the definition of diversity, which had up until this point largely been predicated on BME representation:

diversity does not simply mean work or people from an Asian or African-Caribbean background. It is vital that we move into an understanding of diversity that is as broad as possible, to cover the span of ages, religions, cultures, sexualities, disabilities and socioeconomic backgrounds. There are, for example, new and under represented communities settling in the $\mathrm{UK}$, such as those emigrating from Eastern Europe or fleeing conflict around the world. They should be given the chance not only to find their feet, but to find their voice and to contribute to the culture, diversity and creativity of this country

(McMasters 2010, 11)

It is, of course, absolutely correct to recognise that diversity goes beyond skin colour or ethnicity. However, the concern would be that broadening the definition unwittingly undermines and disavows the specific and particular discriminatory histories and trajectories that the different minority groupings experience and the capacity to respond appropriately to them. Age discrimination and race discrimination can be equally prejudicial but are not the same. Historically, a similar criticism was leveled at Khan's report which did not recognise a "crucial distinction [...] between Black and white immigrant communities whose creative abilities were perceived very differently by British society [...] Black creativity is underlined by a racism that is historically specific" (Owasu 198, 56). It is also worth problematising this point further to recognise that diversity articulates within and across all categories and further that categories such as Black and Asian are themselves internally marked by difference and heterogeneity. 
However, the focused funding initiatives of the 'Creative Case for Diversity' are to be welcomed as a corrective that engages with the cultural specificities of the communities with which they aim to engage and reflect, rather than disavow the reality of cultural difference. Key initiatives pertain to BME led artists and organisations such as:

- Elevate' a $f^{2.1}$ million fund created to develop the strength, management and governance of diverse-led organisations outside the Arts Council's national portfolio created with the stated aim of increasing the diversity of applications in future investment rounds.

- 'Sustained Theatre Fund' a $£ 2$ million fund to support the development of established and emerging Black and Minority Ethnic theatre makers and to increase their representation across the wider theatre sector in England.

Clearly the proof of the efficacy of these schemes will be judged as they come on stream but these tangible signs of practical and specific fiscal support do indicate intent and a commitment to change. However, while increasing the diversity of artist representation is obviously a vital aim, the way in which communities, especially those previously excluded and marginalised, are artistically engaged and enfranchised is not a sine qua non, or something quantifiably addressed in the initiatives.

A final thought on the issue of accessibility is exemplified in the length and complexity of the Arts Council application process, perhaps understandably for a public body distributing funds, but it must surely militate against those emergent and aspiring diverse artists without experience, training or industry knowledge. In this respect the partnering of the new and experienced, BME-led and non-BME led, is a crucial plank of meaningful reform and potential innovation in the sector. While the focus of this chapter is on BME led artists and organisations, it strongly welcomes the aim to, 'cross all social barriers, not only the protected characteristics, but also class and geography', signalled by an increase of funding outside of London from $70 \%$ to 75\% from 2015 - 2018 and 'Unlimited 111', an initiative which supports the development of new work by deaf or disabled artists. 


\section{Performing Difference - Clocks 1888 the greener}

While the opera adhered to a simple broad definition as "a dramatic work in one or more acts set to music for singers and instrumentalists" (OED) which the composer, Martin Ward, scored for four singers and three instruments, piano, cello and violin, it also had artistic, as well as cultural, hybrid ambitions supported by the partner organisations:

Brolly's ambition of a fusion between Opera and Musical theatre, both genres and cast, for this piece compliments our ambitions to explore ways of breaking down preconceptions, developing a wider audience for both and to present more work that pushes the boundaries when it comes to Music Theatre in general.

Susie McKenna, Creative Director, Hackney Empire (2015)

In this respect Hackney Empire only re-opened in 2004 after a major refurbishment having fallen into disrepair after re-opening in the 1980s led by the political theatre company CAST who were the architects of the modern stand - up comedy circuit in the UK. While the artistic economy of Hackney Empire is mixed, with dance, stand-up comedy, theatre and dance prominent, there is a strong community engagement, perhaps evidenced in the fact that during the London riots of August 2011 the theatre remained undamaged while violence raged between the local community and police on the streets outside.

Reading in line with current performance and opera studies to engage, "not only with dramatic texts but with the materiality of performance practices and events and with the institutions and cultural discourses that sustain them" (2012, p. 2), this chapter will examine how the opera can be read as 'performing difference' by attempting to open and destabilise the borders of the form. This is done in the opera by drawing on the influences of the Asian classical tradition, music hall and musical theatre and staging the 'hidden' marginalised histories of the East End in order to inscribe difference within the traditional classical 'western' form. In this way, we can look at the different ways the specific cultural and musical locations of the characters underpinned the production's attempt to “merge the cohesive, over-arching sound world of the 
opera with key elements of these more culturally specific musical languages at the moments when the characters' personalities are most intimately or decisively revealed" (Ward, 2016) into a hybrid cultural form destabilising binary notions such as East/West, Black/White, and Centre/Margin by inscribing difference within the form.

The opera was set in a fictitious clock that ran the work of the 'sweated' labour in the East End of London in 1888. Whilst rooted in the social reality of the time, the dramatic conceit was that the clock is run by a fictional clocketeer: in this instance the Greener of the title. Greener was a cockney Victorian slang term for immigrant and the clocketeer created was a mixed race teenage girl who is uneducated but extremely clever, very much a product of Brah's “diaspora space", of mixed heritage and speaking in many languages alongside English. The singer playing the Greener was from the musical theatre discipline, while the singer playing the Indian character, Ma, had knowledge of the Asian classical tradition. The two remaining parts of The Author and The Coster were to be played by trained opera singers in order to explore the creation of a hybrid form situated between opera and music theatre.

A function of the characters in the opera was to reflect the diversity of the audience, but also the particular 'hidden' histories and diasporic trajectories of the East End of that time. In this respect, in line with Brah, the authenticity and representation of the indigenous white working class character of Coster is key to the work alongside the 'other' marginalized characters. Clearly a methodological and budgetary issue is the number of characters / singers which means only certain histories can be staged in the opera, in this case through the four characters, so a function of the hybrid performance is not to generalise 'otherness' but to inscribe particular difference, extended also to the indigenous white characters, whilst pointing towards a heterogeneous cultural location of creative potential.

I will develop this argument through a close reading of the development of two of the characters, Ma, the elderly Asian woman who looks after the Greener and was brought to Britain as an ayah [nanny] and who draws on the Asian classical musical tradition and Coster, the white Cockney overseer to Greener, who draws on the influence of music hall. 


\section{Clocks 188 the greener}

A well-to-do young man, the Author, travels from his comfortable West End home in London to the slums of the East End in order to ascertain why the people of that place have decided to strike and withdraw their labour. Whilst there he meets the Greener, an extraordinary girl who maintains the towering clock that runs all of the work in the East End. The Author's guide while he is 'slumming' in the East End is Coster - a cockney street seller - who is the overseer to the Greener. Greener is looked after by an old Indian woman, Ma, who fought for independence against the British, then became an ayah (nanny) for a colonial family, but now works in the clock doing 'piece' work for Coster. When not maintaining the clock, Greener works on an invention to map the stars and in her calculations is abreast of Keppler and Newton and reaching towards the work of Einstein. She shows her invention to the Author who is amazed at her intelligence. Coster catches the Greener working on her invention and in the ensuing struggle discovers that time can be extracted from the clock which he then goes on to sell at exorbitant interest to the 'sweaters' on the streets. When the Author returns with an offer of marriage for Greener, she refuses and sends him away, much to Coster's amusement. However Coster's pleasure is short lived as Greener refuses to maintain the clock any further or extract time for Coster. When Coster threatens to harm Greener, Ma intervenes and stabs him and he leaves, but not before he strikes her a fatal blow. Greener holds Ma as she dies and then determines that she will run the clock to destruction.

In 1888 the British Raj was at its height and the production shares historian Rozina Visram's corrective postcolonial mission to perform the 'hidden' presence of Asians in Britain, well before the widely understood postwar migrations of the 1950s and then again in the 'exodus' of Kenyan Asians to Britain in 1968. Visram points out that 'by the eighteenth century, the custom of employing Indian servants and ayahs in British households had become firmly established' $(2002,7)$ and sets out the rationale as to why Indian servants should be employed when there was no shortage of indigenous domestic staff available. Visram suggest two key reasons, one technological and one political, for the increasing employment of ayahs and their subsequent arrival in Britain. The political change following the Rebellion of 1857 was the implementation of The Government of India Act abolishing the East India Company and transferring the power of administration to the Crown, which led to greatly increased numbers of Britons going out to service the Raj.

Technologically, the opening of the Suez Canal in 1869, taking over four and a half thousand miles from the journey, enabled the wives or memsabibs of these workers, to accompany their husbands and still make a visit home. The 
role of the ayah was to "care for the babies, amuse the children and look after the memsahib and the luggage" $(2002,50)$. While the idea was that the ayah would return to India once arrived in England, return fares were not always honoured and the women were often left to fend for themselves.

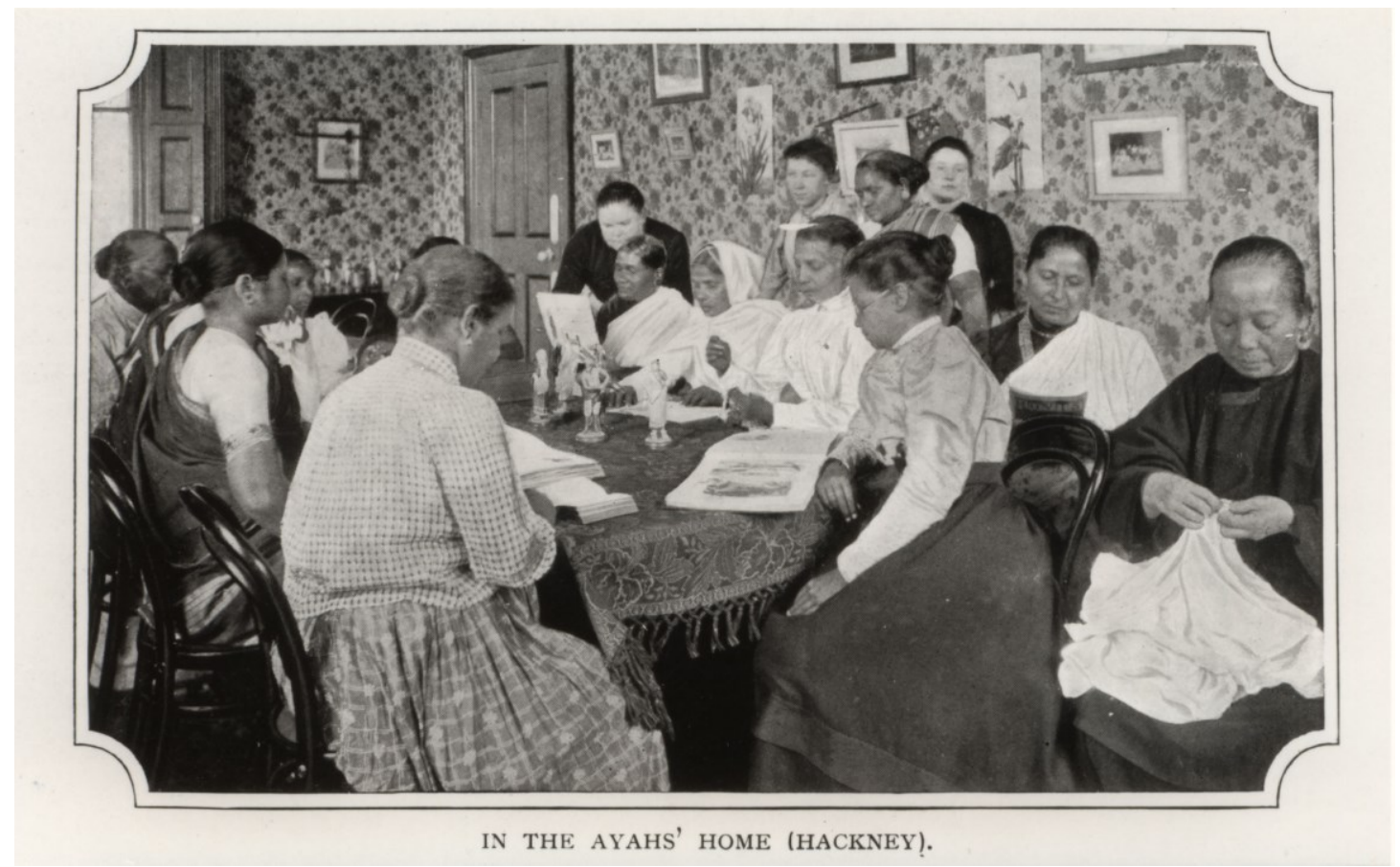

Ayahs' Home in Mare Street, Hackney

Photograph courtesy of Hackney Museum

The plight of destitute ayahs in the East End was first noted in 1855 "when it was reported that 50-60 ayahs were found in one disreputable lodging house in Ratcliffe Highway" (2002, 51). An Ayahs' home was eventually set up in Aldgate in 1891 and in 1900 moved to 26 King Edward Road, Mare Street, Hackney, a site just yards from the Hackney Empire which was built in 1901 by Frank Matchem and run by Oswald Moss. I note this archival research not only as it reflects the hidden historic 'diaspora space' of Hackney, but also as it demonstrates how methodological engagement with archives can be a valuable source of creative material and crucially, audience engagement. Indeed, as can be seen from the photograph above, the archive of Hackney Museum not only served as inspiration and authenticity to the dramatic narrative of the character, but also the development of her costume. 
The development of the character of Ma was influenced by the 'subaltern' approach of Guha (1993) and The Subaltern Studies group, so whilst Rani Lakshmibai was clearly a figure of the Indian elite, albeit as a woman her gender inflects this position, the character of Ma rides by her side as an equal in political struggle if not accepted as an equal in social standing.

I rode with Lakshmi Bhai against the British Raj

We stared death in the face against the British Raj

We women fought for independence of our fate

But now we know our place against the British Raj

An end to caste and creed our women hand in hand

Dignity for our race against the British Raj

Where did it get us but hanged and chained and raped

Thrilled by the hunt and chase against the British Raj

"Deeds not words" our motto and look at where it led

Beware to act in haste against the British Raj

(Hingorani 2016, 73 - 76)

The score here creates a hybrid of Indian and Western classical approaches through libretto, melody and orchestration. The libretto drew on the Asian tradition of the Eastern ghazal form which has its roots in Arabia from the seventh century and came to prominence in the thirteenth and fourteenth century with Persian poets such as Rumi and Hafiz and subsequently Ghalib, writing in Urdu in the eighteenth century, and currently very popular in India and Pakistan. Ghazals started as poetic recitations but are now more understood as Urdu songs. The structure of the poem is usually composed with a minimum of five couplets with each line being of similar length, with the refrain of the first stanza or matla being the most important, repeated at the end of the second line of each subsequent couplet, in this case 'against the British Raj'. The rhyme scheme can be followed through the 
second line of each couplet prior to the refrain; 'face', 'place', 'race', 'chase', 'haste'.

In contrast to the traditional subjects for a ghazal being unrequited love and longing, Ma uses the form to remember and, crucially, share her political past with Greener, operating not only as a dramatic device within the plot but also serving a postcolonial function of the opera to put the Indian resistance to British rule and women's role in it, centre stage. The dramatic irony being that whilst Ma has been an idealistic freedom fighter in her youth, experience has now made her cynical and she advises Greener against subversion, rebellion or action:

So my advice is shut your mouth and open your legs

Or you'll be chod [fucked] against the British Raj

(Hingorani 2016, 76)

In this way the libretto draws on the specific form of the ghazal that allows the author of the poem, in this case $\mathrm{Ma}$, to use the final couplet or maqta to make an authorial point. The libretto, which draws on the Eastern form but utilises 'other' languages alongside English, in this case Hindi, also exhibits a hybrid intertextuality evidenced in the use of the Suffragette motto 'Deeds not Words'. This motto precipitated a move to a form of more direct action from 1912 and the hybrid text connects the political struggle for emancipation and resistance of women in both England and India and symbolises gender solidarity across race through the lens of colonial oppression.

Ghazal gayaki, the art of singing or performing the ghazal is part of the Indian classical tradition, but while the singer playing Ma, Patricia Rozario, was of Asian heritage and had studied the Asian classical tradition, she trained and performed predominantly in classical Western opera. The score developed the form to create a new space between the western classical tradition of reading music and having a fixed score, and the Asian classical tradition that has the freedom of improvisation to create a hybrid musical space inscribed with difference. The word used to describe the musical improvisation within the ghazal is described in western terms as melisma, which is a term for a group of notes sung to one syllable of text that coheres with the Asian tradition. However, it was placed between, rather than within, couplets, creating a new 
form between the improvised and the scored that disrupted and opened the borders of the classical form and inscribed difference within it. The quasiimprovised melisma in the vocal part enables the character of $\mathrm{Ma}$

...to depart from the words and music of the aria's narrative and flow seamlessly into passages of free melodies sung on vowel sounds rather than words, exploring semi and quarter-tone dissonances and the extremes of the soprano range to reflect the extremes of the character's emotional reaction to the story which she is telling.

(Ward, 2016)

In this respect, the hybrid form makes porous the borders of the classical western form, both creating new methodological tools of expression, the ghazal/melisma, inscribing difference. The composer also created a musical accompaniment which explored a descant melody to echo Indian classical tradition through its, "ornamentation of repeating falling appoggiaturas" (2016) so that while the aria was rooted in G major it, "leans towards the harmony of Indian and Eastern music and loosely the Phrygian mode" (ibid) and drew on 'other' instruments in the form of the tanpura or drone instrument. The composer utilised pedal notes in the aria to connect to the Indian classical tradition alongside a sampled recording of the tampura in the sound design:

...rising and falling by step, from tonic, to flattened supertonic (A-flat major), and flattened mediant (B-flat major, stressing the dissonance of B-flat and B-natural), over a pedal note of $G$ or at dramatic moments a pedal note of $\mathrm{F}$. This latter feature of pedal notes also connects into the Indian Classical tradition of the sitar-like Tanpura, which provides a drone over-which melodic instruments or voices may improvise.

(Ward 2016)

While the representation and inscription of diasporic voices such as Ma's are a key sign of the performance, it is also vital that the indigenous voice, in this case of the Coster, is also represented in the 'diaspora space' as 
previously discussed, especially, as a working class character, he exemplifies the 'subaltern' politics of the opera. The character of the Coster, constructed as culturally indigenous to the East End, draws on a range of London vernacular registers from the profane, Cockney slang, the limerick form of the poetic, to the influence of music hall and its related 'patter'.

These may be 'local' or 'popular' cultural forms of expression which are inscribed in the classical opera form, but they also carry with them formal linguistic and musical rules so that the limericks follow the five-line rhyme scheme $\mathrm{AABBA}$ with the appropriate intent, albeit misplaced, at obscene humour:

COSTER: (to greener)

There once was a toff from up west

With his hands up a young darkie's vest

While fingerin' her clock

He came to a stop

Cos he wanted to get her undressed

While the character's casual racism, misogyny and bullying make him purposefully unsympathetic, and indeed he gets his dramatic comeuppance, he articulates the issue of class inequality and the punitive social laws of the time for the local as well as diasporic communities.

The Poor Law Amendment Act of 1834 applied the workhouse as a deterrent to those of insufficient means to keep themselves and was clearly punitive in intent. On 13 November 1888, the East End News confirmed the "total number of paupers in London had risen to 108,638 compared with 104,431 the year before" (Fishman, 2009, 107). East London 'proper' (comprising Tower Hamlets plus Shoreditch, Bethnal Green and Hackney) had 17,000 inmates of workhouses, asylums and hospitals, the rate of destitution being "double the average for the rest of the country" (Fishman 2005, 107). A prevalent view of the time, even for notable social researchers and reformers such as Charles Booth, was in favour of the abolition of out relief, or 'dole', believing "the weekly dole, or O.R. (outdoor relief) administered by a Relieving Officer bound to suspect every assertion, brings out the greed of the applicant, 
destroys his self respect, checks his energies and has a distinct effect of keeping down wages" $(2005,108)$, which, as Fishman points out, is an argument still very much current in policy. In its stead was the threat of the workhouse or 'Bastille'.

The character of Coster embodies the ethos of free market capital driven by his determination to avoid a return to the 'casual ward' in which penniless and homeless men and women could seek refuge but was "a place that no one will go if he can possibly avoid it" $(2005,112)$. Inmates of the casual ward would be locked up at night with the regulation supper of $1 / 2 \mathrm{lb}$ of gruel and $8 \mathrm{oz}$ bread and then the following day would have to break half a ton of stones or pick four pounds of oakum; tarred ropes which had to be painstakingly unpicked by hand. Coster's song, the 'Whistle of the Workhouse', is grounded in the 'subaltern' perspective, on the indigenous British site, researched by Mayhew in the 1850s of the poor and their experience of the 'Bastille' and is a means of humanising the character and drawing the audience's sympathy.

The whistle of the workhouse

The Bastille's blue and white

Sittin in a freezing 'ole

A cell of eight foot by five

Open to the elements

A filthy mattress on the floor

Break an 'arf a ton of granite

Or you don't get out the door.

Won't answer to that whistle.... no more

(Hingorani 2016, 164 - 166)

Ward allows the character of Coster to disrupt the classical form in the score as 'much of Coster's music has a swing to it and when he enters he...drags the music into compound time or into triplets, away from the more regimented meters of other characters' (2016) insisting on his 'voice' within the form. 
If we look at Coster's aria, 'Roll Up', it draws on his working class occupation as a costermonger or street seller and the work of the patterers 'men who help off their wares by long harangues in the public thoroughfares' (Mayhew 2008, 11). The song is set in a 'penny gaff' which were 'shops that have been turned into a kind of temporary theatre (admission one penny) where dancing and singing take place every night' (Mayhew 2008, 49), the disreputable, disruptive sibling of the music hall which mirrors the 'unofficial' London explored by the opera. The aria is in the form of a popular song using a standard verse-chorus structure and creating a 'performance within the performance' (Ward 2016).

\section{Roll Up}

\section{Verse}

Well fluff me off wiv a feather, it's a Coster's market today

Time on tap and punters out there desperate to take it away

Come on greener shift yerself, I'm uppin' yer rate of bait

Sweaters takin' pay-day loans, time is money, don't make me wait

\section{Chorus}

Roll Up! Roll Up! No time to spare

Form an orderly fuckin' line

No time like the present and no present like the time

Coster will supply the time you need

But do kindly remember that

Nec sum adeo cunnus me non habeus ut twat

(Hingorani 2016, 117 - 127)

Coster's aria uses a range of vernacular registers from cockney rhyming slang, patter and cliché alongside classical Latin, usually the preserve of the educated class and formal language. He demonstrates a sophisticated and creative vocabulary often integrating different registers for comic effect, as below, in trying to spare the embarrassment of the Author:

COSTER: ‘Are you wiv' me sir? Dollymop? A judy. Great horizontal. Night flower. Three Penny upright. A young lady of strictly amateur status who must 
seek solace in the arms of unknown gennulmen' strangers for pecuniary advantage. Dirty Puzzle? Harlot?

THE AUTHOR: Well, yes.. Mr Coster... I am indebted to you for your sensitivity on the matter.

COSTER: ... whore.

(Hingorani 2016, 51 - 53)

The use of 'other' languages in the libretto further extends from Hindi to Irish, Jewish, Cockney and Patois vernaculars. There is a methodological aim to create a particular hybrid libretto which linguistically points to both an 'excess' and 'lack in' what we understand to be 'English', which opens the borders of language and performs 'difference' whilst at the same time insisting on inclusion. This use of these 'other' languages also contests the centrality of English on the British stage, meaning that at times elements of the audience may be 'left out' or at least behind those who have a cultural knowledge. This has been discussed previously regarding Tara Arts' 'Binglish' performance practice (Hingorani 2010) that operates to use un-translated words to provide the audience with "an active engagement with the horizons of culture in which these terms have meaning" (Ashcroft et al 2002, 51). There is a clear politics to this linguistically and musically hybrid text as the audience are constantly being made aware of their own and by extension the culturally constructed 'others' constantly shifting position of centrality or marginality.

However, it should also be remembered that, "the 'word' in theatre is never entirely literary, but mediated through the bodies and voices of the actors in a specific mise-en-scene wherein the meaning of a particular theatrical representation is shaped, enunciated, embodied" (Bharucha 2000, 68), which is also why representation is key. This 'embodiment', in its most literal casting sense, is also pertinent to this discussion on representation. While general casting policy in opera which often disavows race and authenticity may be perceived as a norm, albeit violently reactionary in terms of representation, for the theatre world more widely and this production in particular, it is a problematic and heavily contested notion that must be addressed. To have the character of Ma played by an Asian female singer and Greener by a young black 
woman is vital, not only in scribing difference on the stage but also in the diversity of the stage attempting to reflect the diversity of the audience.

In this respect Greener's language exemplifies the creative hybrid location dramatised in the opera :

Greener: Tik hai [All right!] tik hai [all right] , Ma

Me ari hoon [I'm coming] Ya faasti [rude] old loon [fool]

(Hingorani 2016, 21)

MA: You saw the gentleman gora [white boy]

GREENER: The quare [Irish pronunciation of strange] fellow Ma? Why's a toff [Cockney meaning rich] gora [white boy] interested in a clock?

MA: Maybe he sees something he likes?

GREENER: Cha! [Patois expression of impatience] I need to work. The gora [white boy], here? Doesn't add up.

(Hingorani 2016, 78)

The character of the Greener, uneducated but brilliantly clever, a young woman who takes control of her own destiny and refuses the offer of marriage from the 'respectable' Author, is a celebratory embodiment of the creative potential and possibility of the hybrid cultural location and a space for the subaltern, the outsider, the 'other' to speak / sing. In this way the casting of a young Black female musical theatre performer as the central role was purposefully provocative to de-centre the classical opera form and inscribe difference on its stage.

The dramatic structure of the opera purposefully subverts expectation with the Author, the white male upper class character narrating the opening of Act 1, only to have him dismissed by Greener well before the denouement of Act 2. In this respect the Author's journey to the East End exemplified the ambivalent social phenomena of 'slumming' at the time, a form of 
urban social exploration, it bore the obloquy of sensationalism, sexual transgression, and self seeking gratification... [ and therefore] clergymen, journalists, novelists, philanthropists, social investigators, and reformers therefore went to great lengths to contrast their supposedly high minded engagement with social problems with activities of casual 'slummers'

(Koven 2006, 8)

The Author's opening aria stages the notion of slumming as "some sort of 'descent' across urban spatial and class, gender and sexual boundaries" $(2006,9)$ and, in the case of Clock 1888 the greener, race:

I must go down, I must go down

This Orpheus must descend

(Hingorani 2016, 7)

The opera then de-centres the gaze of the Author as the cultural authority and places the 'other' stories centre stage. That is stories, plural.

\section{Connecting Communities and Culture}

Part of the company's audience engagement model alongside the artistic product was to host symposia predicated on developing networks and access for our audience with other cultural and advocacy organizations, ideally in their space. Symposia were hosted for the opera at the British, Doncaster and Hackney Museums and I will focus on the 'Opera Audiences of The Future' symposium at the Hackney Museum as it exemplifies the potential to engage communities through cultural collaboration.

Hackney Museum is located across the road from the Hackney Empire and all its records and collections are connected with the local areas of Hackney, Shoreditch and Stoke Newington. In this respect the Museum is very much a community resource which holds archives not only on indigenous histories of the workhouses and factory but also diasporic communities such as the Asian Ayah's in the East End of London which were dramatized in the opera. The community engagement benefits of hosting the symposium at the 
Museum, which are not possible if the workshop was held at the school, are threefold: the children engage with the museum collection that relates to them and their community; the children see an opera performance that reflects their community and responds to the archive; the children see how the archive and performance can creatively collaborate.

Millfields Community School, who took part in the symposium, serves an area of significant deprivation and its pupils represent a very wide range of ethnic backgrounds, with the largest groups being those of Asian, White, Black Caribbean and Black African heritage. The community is culturally and ethnically diverse: some $8 \%$ of the pupils are Turkish, $6 \%$ African Caribbean, $66 \%$ White British, 11\% from other white European backgrounds and the remainder are from a wide range of ethnic groups represented in smaller numbers. The percentage of pupils from minority ethnic groups is more than twice the National average and, as the schools website suggests, "the school works hard to be culturally inclusive." (2016) The political importance of the libretto mediating between English and 'other' languages is clear when we think of the cultural makeup of the school in which many pupils speak English as an additional language and a large proportion are at the early stages of learning the language.

It is a testament to the appetite of schools to engage with a cultural offer that is representative of their diverse intake and the desire to engage with 'elitist' art forms that the workshop was booked within thirty minutes of it being advertised. The format enabled the children to hear songs from the characters such as $\mathrm{Ma}$, the Asian ayah, and explore specific elements in the museum archive on ayahs and then ask the character questions.

So while one of the children, Suresh, asked why the Indian people were servants, he was also able to demonstrate knowledge that Asians started coming to England in the 1700 s as a result of engaging with the archive. The importance of this engagement with 'other' stories is not only for Suresh, a child of Asian heritage, but also for the class as a whole to be in that 'diaspora space' because "identity is a process...fields of discourses, matrices of meaning, narratives as self and others and the configuration of memories, which once in circulation, provide a basis for identification" (Brah 1996, 247). The 
performance of these particular 'counter narratives', especially embodied by a diverse cast, contests an exclusionary construction of the nation and can create a space for the inclusion of those positioned on the margins. Further, it enabled the children to engage with and make accessible an art form with which they were unfamiliar which was recognised by the teacher of the group.

\section{Dear Dominic Hingorani,}

I just would like to say thank you very much for your wonderful and amazing opera Workshop. I have this opportunity to say that the children in my class enjoyed the workshop and they loved it. I believe it was very beneficial and valuable for them. All my children including SEN children were engaged at all times. Thanks, Mr Mehmet Soylu - Year 5 Class Teacher

It is also an important political function of the workshop that the children can also engage with the artists, musicians and creative team as professional practitioners and ask them questions and gain an insight into professional routes and roles in the Creative industries, and further that through the production, connections and networks are made across cultural organizations for the diverse audience.

The event was a huge success, with the children clearly engaged and the teacher saying he thought every class in his school should see it. It was a pleasure to work with Dominic, Rachana and the whole team. Their passion for opera, music and performance really came across from the first time we met them and no doubt inspired the children to think about opera and their future careers in a new way. It's so exciting for us to be able to offer a workshop as special as this to Hackney pupils; something so different to what we normally do, yet so rooted in what the museum is all about - learning about local history through local people's stories. 
Emma Winch \& Josie Stephens

Heritage Learning, Hackney Museum

These civic engagement strategies alongside the opera were directly aimed at challenging elitism and promoting inclusion and access within communities.

\section{$\underline{\text { Conclusion }}$}

In previous times a BME such as Brolly would have been expected and funded to produce work that primarily reflected the Asian diasporic history of its Artistic Directors, which is clearly discriminatory artistically, and politically problematic if it is the only subject of discussion. The Arts Council is right to recognise that representation is key, but also that "culture can only be excellent when it is relevant, and thus nothing can be excellent without reflecting the society which produces and experiences it" (McMasters, 11). In this way 'performing difference' can, and should be, a catalyst to creative imagination and art form innovation that can enable the arts to engage diverse, new and existing audiences in ways that meaningfully engage with their cultural loci and experiences. Therefore, any conception of diversity must recognise that art must be always, already marked with internal difference and heterogeneity in a way that refutes and problematises borders to become a powerful 'counter narrative' to constructions of the nation, the stories which attempt to tell us who 'we' are, which are exclusionary, racist and discriminatory because;

once the liminality of the nation space is established, and its signifying difference is turned from the boundary "outside" to its finitude "within" the threat of cultural difference is no longer a problem of 'other people. It becomes a question of the otherness of the people as one.

(Bhabha 1994, 150)

In this way we can begin to understand the paradoxical notion of 'vernacular cosmopolitanism' as posited by Bhabha that enables these particular 
cultural articulations inhabited and intersected by many 'differences' within a 'diaspora space' conceptualized by Avtar Brah - indigenous, migrant and diasporic - in a creative engagement that simultaneously challenges homogeneous interior constructions of the nation and is able to look beyond its porous borders. Clocks 1888 the greener exemplified an ambition to 'perform difference' and thereby challenge hierarchical structures between high and low art, opera and music theatre, through its hybrid form allied to a postcolonial aim to tell 'hidden' stories without displacing the 'local' within that 'diaspora space' so that it may engage fully with the plenitude of diversity and its myriad intersections in a way that ensures "performances are sites of resistance... places where meanings, politics, and identities are negotiated... transform and challenge stereotypical forms of cultural representation" (Denzin 2003, 123). 


\section{Bibliography}

Anderson, Benedict. 1983. Imagined Communities - Reflections on the Origin and Spread of Nationalism London: Verso

Arts Council England (2002) 'The Eclipse Report - Developing Strategies to Combat Racism in Theatre'

http://www.artscouncil.org.uk/sites/default/files/downloadfile/Eclipse report 2011.pdf Arts Council England (2014) 'The Creative Case For Diversity' http://www.artscouncil.org.uk/diversity-and-equality/creative-case-diversity Arts Council England 'Equality, Diversity \& The Creative Case - A Data Report 2012 - 2015' 7 December 2015

http://www.artscouncil.org.uk/publication/equality-diversity-creative-case Ashcroft, Bill, Gareth Griffiths, and Helen Tiffin. 2013. Eds. Postcolonial Studies The Key Concepts London: Routledge Bazelgette, Sir Peter, Chair Arts Council England, Keynote Speech 'Arts Council and the Creative Case for Diversity' Saddlers Wells. 8 December 2014 http://rraceweb01.aws.rroom.net/diversity-and-equality/join-creativecaseconversation

Bhabha, Homi K. 1994. The Location of Culture London: Routledge Bhabha, Homi K. 1990. Nation and Narration London: Routledge Bhabha, Homi K. 1996. 'Unsatisfied: Notes on Vernacular Cosmopolitanism', pp. 191-207 in L. Garcia-Morena and P. C. Pfeifer (eds) Text and Nation. London: Camden House.

Brah, Avtah. 1996. Cartographies of the Diaspora - Contesting Identities London: Routledge

Chambers, Colin. 2011. Black and Asian Theatre in Britain - A History London: Routledge

B. Chandra. 1989. India's Struggle For Independence London: Penguin 
N. K. Denzin. 2003. Performance Ethnography: Critical Pedagogy and the Politics of Culture London: Sage

W. J. Fishman. 2005. East End 1888 Nottingham: Five Leaves

R. Guha. 1993. Subaltern Studies Reader, 1986-1995 Minneapolis: University of Minnesota Press

S. Hall. 1992. 'The Question of Culutral Identity' in S.Hall, D.Held, T.

Mulgrew (eds) Modernity and its futures Cambridge: Polity

S. Hall. 1997. Representation: Cultural Representations and Signifying Practices London: Sage

D. Hingorani. 2010. British Asian Theatre - Dramaturgy, Process and Performance Basingstoke: Palgrave

D. Hingorani. 2016. Libretto Clocks 1888 the greener Hackney Empire April 20 22,2016

N. Khan. 1976. The Arts Britain Ignores - The Arts of Ethnic Minorities in Britain Report sponsored by The Arts Council of Great Britain, Calouste Gulbenkian Foundation and The Commission for Racial Equality. London: The Commission For Racial Equality

S. Koven. 2006. Slumming: Sexual and Social Politics in Victorian London Princeton: Princeton University Press

London Borough of Hackney (2009) 'Hackney's Sustainable Community Strategy $2008-2018$

http://www.hackney.gov.uk/media/2707/Sustainable-community-strategy2008-2018/pdf/scs

London Borough of Hackney (2010) 'Creative Hackney Cultural Policy Framework'

http://www.hackney.gov.uk/media/2469/Creative-Hackney-cultural-policyframework/pdf/cultural-framework

London Borough of Hackney (2013) 'State of The Borough Report' Section 3 'Improve Quality of Life and Promote Safety and Cohesion' http://www.hackney.gov.uk/media/2712/Section-3-Improve-quality-of-lifeand-promote-safety-and-cohesion/pdf/Improve-quality-of-life-and-promote$\underline{\text { safety-and-cohesion }}$ 
London Borough of Hackney (2013) 'Census 2011 - Ethnicity, Identity, Language and Religion in Hackney' http://www.hackney.gov.uk/statistics-evidence-plans-and-strategies

B. McMasters (2008) 'Supporting Excellence in the Arts - from measurement to judgement'.

http://webarchive.nationalarchives.gov.uk/+/http:/www.culture.gov.uk/imag es/publications/supportingexcellenceinthearts.pdf

W. MacPherson (1999) 'The Stephen Lawrence Enquiry' https://www.gov.uk/government/uploads/system/uploads/attachment data/ file/277111/4262.pdf

K. Owasu. 1986. The Struggle For Black Arts in Britian - What Can We Consider Better Than Freedom. London: Commedia Press.

N. Till. 2012 The Cambridge Companion to Opera Studies Cambridge: Cambridge University Press

R. Visram. 1986. Ayahs, Lascars and Princes London: Pluto Press

R. Visram. 2002. Asians In Britain London: Pluto Press

M. Ward. 2016. Interview with the Composer Clocks 1888 the greener 16 May 2016

J. White. 2007. London in the 19'th Century London: Vintage 